\title{
Breast Cancer Period Prevalence in a Hazard-Exposed Cohort at Hermosillo, Sonora, Mexico: A Report from 2013-2019
}

\author{
DE Villa-Guillen ${ }^{1 *}$, M Jara-Marini' ${ }^{2}$, AI Valenzuela-Quintanar ${ }^{2}$, G Caire-Juvera ${ }^{2}$, I Anduro-Corona ${ }^{2}$, E Ruiz- \\ Bustos $^{3}$ and JA Villa-Carrillo ${ }^{4}$ \\ ${ }^{1}$ Departamento de Ciencias Químico Biológicas, Universidad de Sonora, Mexico \\ ${ }^{2}$ Centro de Investigación en Alimentación y Desarrollo AC (CIAD), Mexico \\ ${ }^{3}$ Departamento de Ciencias Químico Biológicas, Universidad de Sonora, Mexico \\ ${ }^{4}$ Departamento de Matemáticas, Universidad de Sonora, Mexico
}

\begin{abstract}
Breast cancer is the leading cause of female cancer-related deaths in Mexico. Residential exposure to industrial-derived hazards may increase cancer risk. Hermosillo is one municipality with high breast cancer prevalence in Sonora, Mexico. However, the relationship between breast cancer and hazards needs further investigation. This retrospective observational study evaluated the associations between breast cancer period prevalence (years 2013-2019) and residential exposure to potentially hazardous sites (PHS) in Hermosillo. Clinical data $(n=912)$ of breast cancer cases were collected from 6-year-old files. Cluster analysis identified regions of period prevalence. Proximity analysis classified neighbourhoods by PHS-exposure, then calculated odds ratio (OR) for breast cancer risk. Age distribution analysis evaluated the risk for PHS-exposed vs non-PHS-exposed groups. Six neighbourhoods classified as high-high breast cancer clusters. Highly industrialized neighbourhoods ( $\geq 7$ industries $v s \leq 6$ industries) presented higher risk (crude OR $=1.69$ ), as well as those in proximity to a gas power plant ( $\leq 4 \mathrm{~km} v s \geq 4 \mathrm{~km}$, crude OR $=1.55$ ) or to a residual water site ( $\leq$ $3 \mathrm{~km} v s \geq 3 \mathrm{~km}$, crude $\mathrm{OR}=1.45$ ) (all $p$-values $<0.0001$ ). Age distribution analysis showed an older population in the PHS-exposed group. Larger cohorts will confirm our findings.
\end{abstract}

KEYWORDS: Breast cancer risk; Environmental hazards; Observational studies

ABBREVIATIONS: PHS: Potentially Hazardous Sites; RWS: Residual Water Sites; HAPs: Hazardous Air Pollutants; GPP: Gas Power Plants

\section{INTRODUCTION}

\section{Geography of Breast Cancer in Mexico}

Breast cancer is considered the most common malignancy diagnosed in women worldwide and the leading cause of female cancer-related deaths in developing countries Ferlay et al. [1]. A population-based study conducted by the National Institute of Statistics and Geography (INEGI) indicated breast cancer as the main cause of female morbidity in 2014 in Mexico INEGI [2]. Moreover, breast cancer represented the leading cause of cancer mortality in Mexican women from the period 2000-2013; MoharBetancourt et al. [3]. Studies by the Health Secretary of Mexico (SS) also showed breast cancer as the main cause of cancer-related deaths in 2002 [4]. The distribution of breast cancer prevalence, though, is not homogeneous in Mexico. There are sub-regional
Quick Response Code:

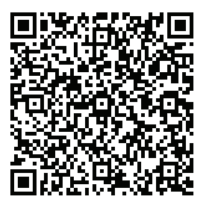

Address for correspondence: DE Villa-Guillen, Departamento de Ciencias Químico Biológicas, Universidad de Sonora, Mexico

Received: November 16, 2020 Published: December 22, 2020

How to cite this article: Villa-Guillen DE, Marini MJ, Valenzuela-Quintanar AI, Caire-Juvera G, Anduro-CI, Ruiz-BE, Villa-Carrillo JA. Breast Cancer Period Prevalence in a Hazard-Exposed Cohort at Hermosillo, Sonora, Mexico: A Report from 2013-2019. 2020 - 2(6) OAJBS.ID.000242. DOI: $10.38125 / O A J B S .000242$ 
variations in breast cancer mortality across the country from the period 2001-2011, with a significant increase in mortality rates for the Southwest (annual percentage change, APC 2.7\%, $p<0.05$ ) and the Center-North regions of Mexico (APC 1.7\%, $p<0.05$ ) Soto-Perezde-Celis et al. [5]. Another study showed twelve entities sustaining the highest breast cancer rates in the country. Among those, Sonora is reported with high rates of breast cancer morbidity and mortality Castrezana-Campos [6]. Furthermore, according to INEGI, Sonora revealed the highest breast cancer mortality rate in the country in 2015, with 16.25 deaths per 100,000 women INEGI [7]. More research is needed that aims at evaluating the associations of breast cancer rates and geographical regions in Sonora, specifically Hermosillo, Sonora.

\section{Exposure to Hazardous Air Pollutants (HAPs) and Breast Cancer Risk}

Epidemiological data indicates anthropogenic-derived air pollutants as potential human carcinogens Garcia et al. [8]. Two investigations conducted within the California Teacher's Study suggest a link between breast cancer risk and hazardous air pollutants (HAPs) in urban areas Garcia et al. [8]. Long-term exposure to specific chemicals such as acrylamide, benzidine, carbon tetrachloride, ethylidene dichloride, and vinyl chloride was related to an increased burden in hormone-responsive breast cancers Garcia et al. [8]. A higher risk of non-hormone responsive breast cancer was related to air pollution with benzene Garcia et al. [8]. Hormone receptor-negative breast cancers were related to cadmium exposure Liu et al. [9]. Other reports showed no associations between HAPs' exposure and breast cancer burden. A cross-sectional analysis within the Nurses' Health Study indicated no relationship between HAPs' exposure and breast cancer risk, neither to an overall increased incidence nor to specific breast cancer subtypes in the U.S.

In Mexico, scarce studies are evaluating HAPs' exposure by geographical regions. A report in 2010 by the Commission for Environmental Cooperation (CCA) indicated high emissions of nitric dioxide (range 16.4- 61.8 thousand metric tons) and sulphur dioxide (range 65,000-130,000 metric tons) in several localities in the state of Sonora [10]. However, few studies aimed to assess the relationship between industrialized areas and the breast cancer burden in Mexico, where highly industrialized municipalities across the country also showed a high burden of this disease. We need more investigations that aim at evaluating the relationship between HAPs and breast cancer rates in Sonora [11-13].

\section{Contaminated Water Sources (CWS) and Breast Cancer Risk}

Drinking water from sources impacted by wastewater, run-off from agricultural lands, or contaminated wells present a potential pathway of human exposure to hazardous chemicals Kuch et al. [14]; Rudel et al. [15]. Improper disposal from industrial operations and small businesses can also contribute to chemical exposure Moran et al. [16]. Specific hazards, like tetrachloroethylene (PCE) and organic solvents found in contaminated drinking water can accumulate in mammary tissue and may increase breast cancer risk Labreche et al. [17]. Some case-control studies indicate slightly to moderate increases in breast cancer burden with high PCE exposure Aschengrau et al. [18]; Gallagher et al. [19]. However, other studies show inconsistent associations between chemical hazards in drinking waters and breast cancer rates Brody et al. [20]. Discrepancies in findings can be due to regional variations in hazardous exposure by water supply, methodological limitations for exposure assessment, and difficulties to retrospectively collect information about potentially affected individuals.

In Mexico, few studies evaluated geographical exposure to CWS and breast cancer burden. The CONAGUA (National Water Commission) identified distinct geographical areas across the country with CWS CONAGUA [21]. In the state of Sonora, Hermosillo municipality figures as a region of interest CONAGUA. Previous studies by the SINA (National Water Information System) identified high concentrations ( $\geq 45 \mathrm{mg} / \mathrm{l}$ ) of hazardous chemicals in several wells within the Hermosillo municipality SINA [22]. Among the hazards found by SINA were nitrates, benzene, aromatic compounds, DDT, iron, magnesium, and arsenic. Exposure to these has been related to breast cancer development Hiatt et al. [23]. The preceding results suggest the need to evaluate possible associations between these elements and breast cancer in Hermosillo, Sonora.

\section{Innovation and Objectives}

Hermosillo municipality is a geographical region with high breast cancer prevalence in Sonora, Mexico. The potential associations of breast cancer burden with residential exposure to environmental hazards, though, remains to be elucidated. This observational retrospective study aims to evaluate statistical associations between breast cancer prevalence and residential exposure to hazardous pollutants (number of industries, gas power plants (GPP), and residual water sites (RWS)) from the period 2013 to 2019. For this aim, we set the following goals: (1) to create a database of female breast cancer cases as reported in hospital files from the period 2013 to 2019, (2) to geolocalize potentially hazardous sites (PHS) using reports from government databases INEGI [24] and (3) to evaluate potential associations between residential exposure to PHS and breast cancer period prevalence by using a statistical approach. In this study we seek to provide evidence of a potential link between hazardous pollutants and breast cancer period prevalence at Hermosillo municipality. Future studies derived from the present investigation may focus on breast cancer prevention policies in high-risk populations.

\section{METHODS}

\section{Breast Cancer Database}

Source population and subject selection criteria: This is an observational retrospective study that collected breast cancer cases (new and pre-existing) reported from the period of January $1^{\text {st }}, 2013$ to September $20^{\text {th }}, 2019$. The REDCap platform Harris [25] was used to create the breast cancer database. Clinical files were transcribed from physical records registered in private hospitals CIMA, Hospital San José, and Clínica del Noroeste; and public hospitals Hospital General del Estado de Sonora Ernesto Ramos Bours (HGE) and Centro Estatal de Oncología Dr. Ernesto Rivera Claisse (CEO). The participating hospitals are located in Hermosillo, Sonora, Mexico. The breast cancer database had the following inclusion criteria:

Female breast cancer cases (current/survivor/deceased) available at hospital archives from the period of January $1^{\text {st }}, 2013$ to September $20^{\text {th }}, 2019$.

Patients who were current Hermosillo residents; (3) patients had an ID-verifiable residential address (as registered at the National Electoral Institute (INE) or their medical insurance card). 
The database had the following exclusion criteria:

Male breast cancer cases.

Former Hermosillo residents.

Non-Hermosillo residents.

Unavailable or non-verifiable residential address.

Non-cancer patients.

Patients diagnosed with neoplasia(s) other than breast cancer. The sample size included all breast cancer cases in compliance with the inclusion criteria $(n=949$ for Hermosillo municipality) as reported by local hospitals. Given the small sample size for rural communities, this study focused on breast cancer cases from Hermosillo city ( $n=912$ ).

Variables of Breast Cancer Database: The breast cancer database collected information from clinical files available in hospital archives. For this database, the Safe Harbor Approach was used to remove 18 potential identifiers HHS [26] to comply with national LFM [27]; DOF [28] and international regulations for the protection and privacy of human subjects.

Variables related to residential information included the following: zip code of current and former residence(s), neighbourhood of current and former residence(s), current location of residence, and former location of residence. In cases of move-outs, the analysis was based on the oldest residential information (residence location $\geq 10$ years old) available from clinical files. This last consideration was done based due to timelatency for tumour development in adulthood, as previously indicated in environmental proximity analyses Brender [29]. This study did not collect private addresses and was limited to register neighbourhoods and zip codes-only.

Variables related to breast cancer information included the following: age at the time of diagnosis, familiar history of cancer, personal history of cancer, breast cancer type, classification of tumour by SBR (Scarff-Bloom-Richardson), classification of tumour by TNM, tumour grade, breast density by mammography (BI-RADS classification), current treatment (chemotherapy, radiotherapy, surgery, breast implants, porth-a-cath), and current diagnosis. Breast cancer cases older than January $1^{\text {st }}, 2013$ were not available to be part of the sample.

Other variables of breast cancer database: Each patient record was assigned a unique ID number to prevent duplicity. Database included information of the following potential confounders: highest degree of education (elementary school, junior high school, high school, technical career, university); religion (atheist, Catholic, Christian, Mormon, Jehovah Witness, other; occupation (homemaker, employee, teaching, engineer, accountant, own business, retired, other); alcohol consumption (former/non-consumer/social consumer ( $<7$ drinks per week) /alcoholism ( $>7$ drinks per week) and tobacco (former/nonconsumer/passive smoker/current smoker/not-included); weekly red meat consumption (non-consumer/from 1-2 times/from 3-4 times/from 5 times or more/not included); BMI, exercise habits (yes/no/not-included), number of live births, age at menarche, menopausal status (premenopausal, peri-menopausal, menopause, postmenopausal, non-included), use of hormonal contraception (yes/no/not included), use of hormonal replacement therapy (yes/ no/not included), elements of metabolic syndrome as defined by the NCEP ATP III criteria Huang [30], prior chronic illnesses other than neoplasia, prior malignancies other than breast cancer, and red blood type. The variables of race and ethnicity were not collected, as the population at Hermosillo municipality is constituted by Hispanics, considering it as a homogenous population.

Ethics Statement: This study was reviewed and approved by the Institutional Review Board (IRB) from public (HGE, CEO) and private health institutions (CIMA, Hospital San José, Clínica del Noroeste) participating in this study, as well as from the IRB of University of Sonora, and the Secretary of Health of Sonora. The national regulations in Mexico as established by the General Law in Health for Clinical Research and according to Article \#17, considered this study as without risk for the individual SSA [31].

\section{Exposure Assessment to Potentially Hazardous Sites (PHS)}

Location of PHS: The coordinates (latitude and longitude) of active industries, gas power plants (GPP), contaminated water sources (CWS), and garbage disposals at Hermosillo municipality were obtained through the INEGI Census 2010 and projected onto a map by conversion to Universal Transverse Mercator System (UTM) zone $12 \mathrm{~N}(12 \mathrm{~N})$.

The coordinates (latitude and longitude) of agricultural lands contaminated with organochloride pesticides (OCPs) were obtained from Leal-Soto and collaborators Leal-Soto et al. [32]. The coordinates converted to UTM zone $12 \mathrm{~N}$ for their projection onto a map (ArcGIS version 10.7.1). Sampling methods and OCPs' analyses were conducted as previously described Leal-Soto et al. [32]. Briefly, OCPs were collected and analysed from active, in-rest, or abandoned agricultural lands located at La Costa de Hermosillo. Field selection criteria included the recent historical use of OCPs (1950-2000), qualifying them as potentially contaminated by its former use. Farmers applied OCPs in a dose concentration of 3 to $8 \mathrm{~kg}$ ha-1 twice per month, per crop cycle. This dosage is superior to that recommended in the official guidelines ( 0.5 to $1.5 \mathrm{~kg}$ ha- 1 ) CCGRS [33]; SARH [34]. The selected fields included cotton, wheat, safflower, corn, and citric crops. Field owners authorized the soil sampling of their lands $(n=20)$ following regulations as established by the National System of Environmental Monitoring INECC-CCA [35]. Five samples were (1.5 $\mathrm{kg}$ each one) collected from each field (at surface-level and $60 \mathrm{~cm}$ underground) following the EPA guidelines EPA [36] for the zigzag scheme or squared sampling method. Soil samples were stored in brown paper bags and kept at $-20{ }^{\circ} \mathrm{C}$ until their extraction by matrix solid-phase dispersion (MSDD) and analysis by gas chromatography Leal-Soto et al. [32].

Moreover, the coordinates (latitude and longitude) of heavy metals in urban dust were obtained from available research studies Garcia-Rico et al. [37] and projected onto a map by conversion to UTM zone $12 \mathrm{~N}$. Methodology for sampling and heavy metal analysis are described by Garcia-Rico et al. [37]. Briefly, sampling of dust was collected from urban streets and parks (particle size $<325(-44$ $\mathrm{mm}$ ). The total concentration of heavy metals was determined with fluorescence ray-X portable equipment, using a portable analyzer NITTON XLt3 of Thermo Scientific Garcia-Rico et al. [37].

The coordinates (latitude and longitude) of contaminated wells and residual water sites (RWS) were obtained from INEGI Census 2010 and of previous investigations conducted by Gomez-Alvarez et al. [38]; Gomez-Alvarez et al. [39]. Reported wells with metals and RWS were projected onto a map by conversion to UTM zone 12 $\mathrm{N}$. The methodological approach for wells' sampling and chemical analysis are described fully by García-Rico et al. [40]. Concisely, 
surface water samples were collected at distinct locations of the Sonora River, using polyethylene of $1 \mathrm{~L}$ bottles previously conditioned (rinsed with $0.2 \mathrm{M}$ nitric acid, HNO3). Once in the laboratory, samples were filtered (polycarbonate $0.4 \mathrm{~mm}$ filters, Nucleopore, Whatman), and added $2 \mathrm{~mL}$ of 14 M HNO3 for metals' analysis which was performed in Inductivity Coupled Plasma-Optic Emission Spectrophotometry (ICP-OES VARIAN 730-ES) according to the manufacturer's specifications Calderon [41].

Industries considered as potential sources of chemical hazards, are the following: production of industrial laminates, furniture, coolers and $\mathrm{AC}$, dental laboratories, production of pesticides and fungicides, manufacturers of orthopedic materials, candle production, chemical laboratories, metal production, automobile assembly, manufacturers of agricultural products, technology machinery production and assembly, manufacturers of cleaning products, electronics production and assembly, production of dyes and construction materials, iron foundries, printer suppliers, welding shops, production of toys and jewelry, manufacturers of chemical products, aquaculture products, polymer and plastic production, clinical hospital products, mechatronics and electrics, and other related industrial manufacturers.

\section{Criteria for Assessment of Residential Exposure to PHS}

Potentially hazardous sites (PHS) per neighbourhood: In this study, neighbourhoods are considered as a geographical unit. Residential exposure will be evaluated in terms of the variables: number of industries, GPP, and RWS. The cut-offs for highly industrialized neighbourhoods and low-industrialized locations will be defined using regression analysis. The cut-offs for GPP and RWS-exposure will be defined by proximity analysis where neighbourhoods within the established cut-off values are considered as exposed, and locations beyond them are classified as non-exposed.

Proximity analysis: The literature reports distinct environmental proximity analyses to assess PHS residential exposure, where the most common approach is distance-based analysis as defined by buffer Brender et al. [29]. In this study, geographical information software (ArcGIS version 10.7.1) was used to calculate the radial distances (in $\mathrm{km}$ ) between PHS and neighbourhoods. According to radial distances (in $\mathrm{km}$ ) to one or more PHS, neighbourhoods with reported breast cancer cases classified as PHS-exposed or non-PHS exposed. Buffer analyses defined cut-off values for radial distances to PHS (in km). In detail, a PHS of interest was the origin of multiple ring buffers, with a buffer unit of $1 \mathrm{~km}$. The cut-off values defined for PHS exposure distance-based analyses were the following: $X \leq 4 \mathrm{~km}$ for GPP or industries, $\mathrm{X} \leq 4 \mathrm{~km}$ for RWS, and $\mathrm{X} \leq 1 \mathrm{~km}$ for garbage disposals, where $X$ represents the core of the neighbourhood of interest. Neighbourhoods located beyond the cut-off values to PHS were considered non-exposed.

\section{Potential Sources of Bias}

In this study, we considered the following variables as potential sources of bias:

Time of residence: The database included women with IDverified address of 10 years or more. In general, tumour screening detects cancer that was on development for a minimum of 10 years Brender et al. [29]. For this reason, residential exposure to hazards needs to consider the location of a minimum of 10 years.

Access to media and information: Prior demographic analysis of breast cancer patients considered accessibility to information through the internet and communication media (TV, radio, cell phone, landline phone). Neighbourhoods with reported breast cancer cases and those without them showed no difference in communication media and access to information.

Socioeconomic status: Neighbourhoods with breast cancer cases were compared to those without them. Prior demographic analysis indicated no differences for the following variables:

Women economically active.

Women non-economically active.

Women with completed high school or some college.

\section{Statistical Methods}

In this study, cluster analysis identified geographical patterns of breast cancer period prevalence (years 2013-2019). The odds ratio (OR) was used to give evidence of an association between hazards and breast cancer in Hermosillo residents. Breast cancer patients were compared in terms of age distribution and hazard exposure using neighbourhood as the geographical unit. Data available from INEGI of non-breast cancer patients included only age by range, here defined as the number of women equal or older than 18 years old. For this reason, partial or total adjustment for ORs could not be made.

Breast cancer database (Years 2013-2019): The breast cancer database created in this study served to provide the number of cases per neighbourhood, as reported in hospital files from the period of January $1^{\text {st }}, 2013$ to September $20^{\text {th }}, 2019$. The sample size for the present study included all the cases collected from the public and private health institutions that agreed to collaborate in this investigation. No sampling strategy was employed in this case, as the intent was to collect all the breast cancer cases available in hospital files. The hospitals granted IRB approval to acquire data from the patient's file in full extent, with the agreement to de-identify 18 potential personal identifiers by the Safe Harbor approach for data analysis.

This study created a unique breast cancer database in cloud format using the REDCap platform. There is no data linkage with other electronical databases. For this reason, there are no methods for data linkage in this investigation.

Geographical patterns of breast cancer period prevalence (Years 2013-2019): The cluster analysis approach was used to detect geographical patterns of breast cancer prevalence from the period 2013-2019. To this end, the number of the female population (women $\geq 18$ years old) by neighbourhood was obtained according to INEGI Demographic Census 2010.

The breast cancer period prevalence was calculated as follows: $100 \mathrm{X}=[$ (number of breast cancer cases reported in years 2013-2019) / (number of women $\geq 18$ years old)]. Statistically significant hot spots, cold spots, and spatial outliers were detected using Anselin Local Moran's I. Spatial relationships among features were defined by contiguity edges-only, with a number of permutations of 499 (ArcGIS version 10.7.1.).

Estimation of breast cancer risk by PHS exposure: The odds ratio (OR) and 95\% of confidence intervals (95\% CI) estimated the likelihood of breast cancer risk through comparison between PHS-exposed and non-PHS-exposed neighbourhoods previously reported with breast cancer cases (SAS Institute, Inc., Cary, N.C.). 
Additionally, distribution analysis by age was conducted between breast cancer cases located in PHS-exposed neighbourhoods versus their non-PHS-exposed counterparts. The aim was to observe differences in age distribution by PHS exposure.

The objective of the statistical analysis is to verify a possible decrease in the influence of the risk factor as distance to the core increases. Given a PHS location, three subpopulations were defined by their radial distance (in $\mathrm{km}$ ) to the PHS of interest. The cut-off values for this radial distance to PHS were the following: $0 \leq \mathrm{X}<2$ $\mathrm{km}$ (subpopulation 1), $2 \mathrm{~km} \leq \mathrm{X}<4 \mathrm{~km}$ (subpopulation 2), and $\mathrm{X}>$ $4 \mathrm{~km}$ (subpopulation 3), where X represents a PHS of interest. The subpopulations were compared by OR with $95 \%$ CI to estimate the likelihood of breast cancer risk.

The three subpopulations give a total of six comparisons. To evaluate if the influence of environmental hazards is affected by radial distance, subpopulation 1 was compared with subpopulation 2 and with subpopulation 3. Additionally, subpopulation 2 was compared with subpopulation 3 . This analysis assessed if the effect of hazardous exposure decreases with radial distance (in km).

Age distribution and PHS exposure: The analysis compared the age distribution of breast cancer patients residentially exposed to all three PHS (highly industrialized neighbourhoods, GPP-exposed, and RWS-exposed) versus their non-exposed counterparts. The aim was to characterize the exposed subpopulation in terms of age, considering aging as a risk factor for cancer development.

\section{Key Assumptions and Limitations}

This research considers the female subpopulation ( $\geq 18$ years old) residing in a neighbourhood as a unit of analysis. The measure of effect for each unit is given by the odds ratio comparing the likelihood of breast cancer in PHS-exposed neighbourhoods versus their non-PHS-exposed counterparts. This ecological study estimated breast cancer likelihood at the unit level (neighbourhood), not for an individual with or without breast cancer.

\section{RESULTS}

\section{Characteristics of the Study Population in the Hermosillo Municipality}

The INEGI Census 2010 reports 281,267 women equal or older than eighteen residing at the Hermosillo municipality. Such population is distributed by neighbourhoods; therefore, the information on the number of women by neighbourhood is available. The previous information allowed us to determine the density of cases in each neighbourhood.

The breast cancer database included 1,916 cases reported in hospital archives (CIMA, Clínica del Noroeste, Hospital San José, HGE, CEO) from the period of January $1^{\text {st }}, 2013$ to September $20^{\text {th }}, 2019.967$ breast cancer cases were not included as those women reported to reside outside of Hermosillo municipality. The remaining 949 breast cancer cases were current Hermosillo residents, which correspond to the $0.34 \%$ of the female population equal or older than 18 years.

The present analysis included 947 breast cancer cases, as two individuals had no verifiable residential address by ID or medical insurance card. From those 947 breast cancer cases, 912 cases (96.3\%) were from Hermosillo city, 22 cases (2.31\%) were from Miguel Aleman, and 14 cases (1.48 \%) were from rural communities at Hermosillo municipality (Bahia de Kino, El Choyudo, El Triunfo, La Yesca, Mesa del Seri, Real del Alamito, San Pedro El Saucito, Zamora); (Figure 1). Due to the small number of cases reported in rural communities, the present study focused on the analysis for Hermosillo city-only.

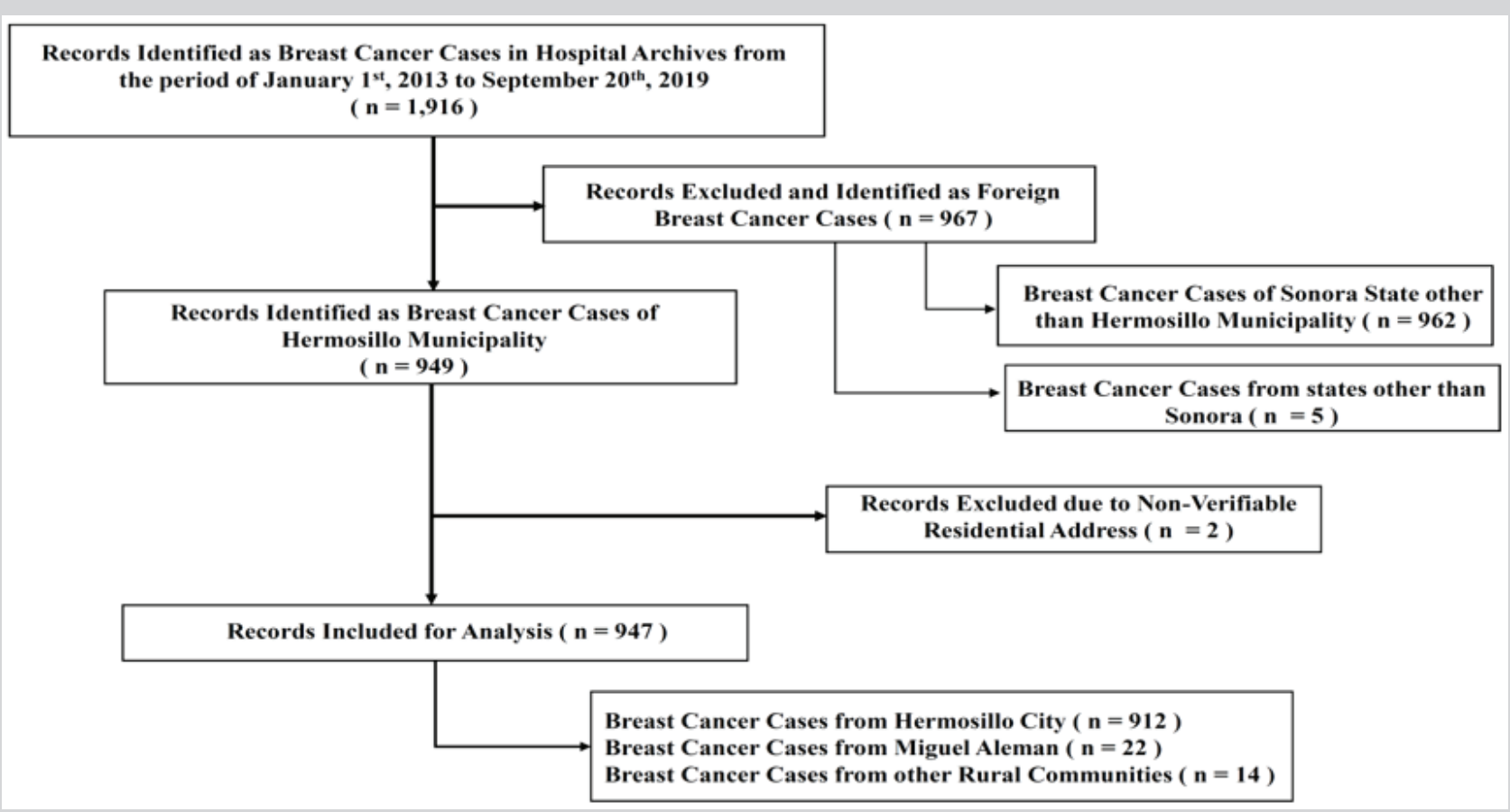

Figure 1: Consort diagram of breast cancer study population at Hermosillo municipality. 


\section{Geographical Patterns of Breast Cancer Period Prevalence (Years 2013-2019) in Hermosillo Municipality}

Geographical patterns of breast cancer period prevalence (Years 2013 to 2019) in Hermosillo city: In this study, Local Anselin Moran's I detected H-H clusters of breast cancer period prevalence (January $1^{\text {st }}, 2013$ to September 20 2019 ) 2019 for six neighbourhoods (all $p \leq 0.05$ ) across Hermosillo municipality. All of them are located in Hermosillo, the capital of the state of Sonora.

The west area of Hermosillo city contains three $\mathrm{H}-\mathrm{H}$ neighbourhoods, all of them at a radial distance of $\leq 3 \mathrm{~km}$ from inactive residual water sites. From those three, two of them are contiguous (zone $12 \mathrm{~N}, 499,870.370 \mathrm{~m} \mathrm{E} / 3,216,269.563 \mathrm{~m} \mathrm{~N}$; and $499,914.414 \mathrm{~m} \mathrm{E} / 3,216,842.126 \mathrm{~m} \mathrm{~N}$ ) and are within the same zip code (83245). The third neighbourhood (zone $12 \mathrm{~N}, 497,315.856$ $\mathrm{m} \mathrm{E} / 3,217,238.516 \mathrm{~m} \mathrm{~N}$ ) is within a radial distance of $<3 \mathrm{~km}$ from the other two sharing the same zip code. The northwest side contains one H-H neighbourhood (zone $12 \mathrm{~N}, 497,007.553 \mathrm{~m} \mathrm{E} /$ $3,221,422.635 \mathrm{~m} \mathrm{~N}$ ), located at a radial distance of $\leq 1 \mathrm{~km}$ from a garbage disposal site (zone $12 \mathrm{~N}, 498,030.990 \mathrm{~m} \mathrm{E} / 3,221,208.504$ $\mathrm{m} \mathrm{N}$ ). The southeast of Hermosillo city contains two H-H clusters, and those neighbourhoods are reported to contain heavy metals in samples taken from urban dust from streets and parks (Neighbourhood "A" with $\mathrm{Mn}=625 \mathrm{mg} / \mathrm{kg}$, and $\mathrm{Pb}=78.82 \mathrm{mg} / \mathrm{kg}$; neighbourhood "B" with $\mathrm{Cr}=183.79 \mathrm{mg} / \mathrm{kg}$, and $\mathrm{Pb}=142.79 \mathrm{mg} /$ $\mathrm{kg}$ ). Those two neighbourhoods are within a radial distance $\leq 2 \mathrm{~km}$ from each other (zone $12 \mathrm{~N}, 504,538.965 \mathrm{~m} \mathrm{E} / 3,213,010.355 \mathrm{~m} \mathrm{~N}$ for Neighbourhood "A"; and 506,036.439 m E/ 3,212,922.268 m N for Neighbourhood "B"); (Figure 2).

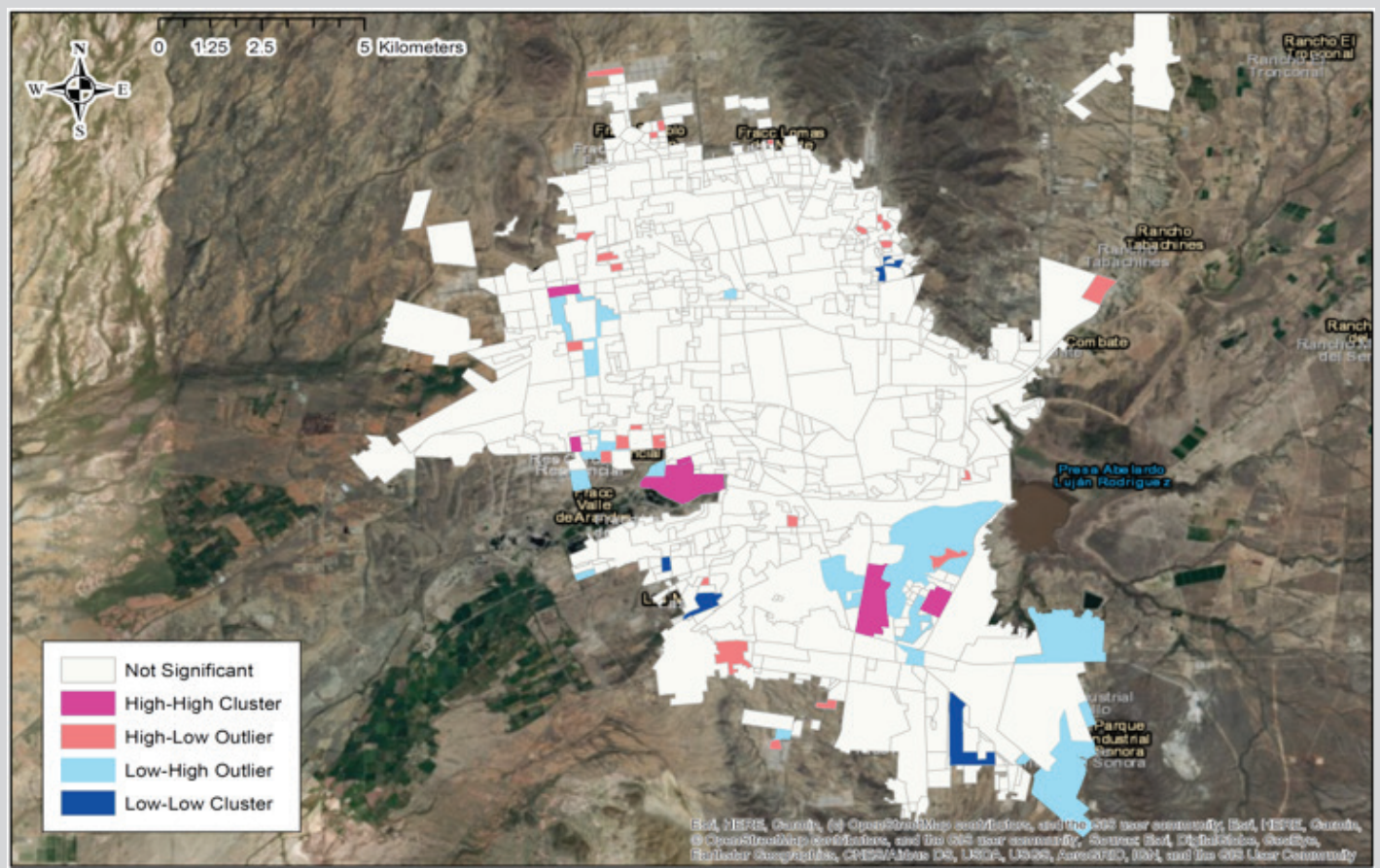

Figure 2: Spatial clusters (Local Anselin Moran's I) of breast cancer period prevalence (January 1 ${ }^{\text {st }}, 2013$ to September $20^{\text {th }}, 2019$ ) at Hermosillo city. source: INEGI census 2010, clinical databases from hospitals HGE, CEO, clínica del noroeste, Hospital San José, and CIMA. projected coordinate system: WGS84 UTM 12 N. Geographic coordinate system: WGS84.

An additional geographical pattern of breast cancer period prevalence indicates cold spots (L-L clusters) for seven neighbourhoods across Hermosillo municipality (all p-values < 0.05). From those cold spots, four of them belong to Hermosillo city. Two of those L-L clusters are located in the southwest area (zone $12 \mathrm{~N}, 499,465.172 \mathrm{~m} \mathrm{E} / 3,213,979.309 \mathrm{~m} \mathrm{~N}$; and 500,486.977 m E/ $3,213,054.398 \mathrm{~m} \mathrm{~N}$ ) and are within a radial distance $\leq 2 \mathrm{~km}$ from each other. Also, those cold spots are close to two high-low (H-L) outliers (<3 km) (zone $12 \mathrm{~N}, 500,381.725 \mathrm{~m} \mathrm{E} / 3,213,508.400 \mathrm{~m} \mathrm{~N}$; and 500,980.263 $\mathrm{m} \mathrm{E} / 3,211,583.351 \mathrm{~m} \mathrm{~N}$ ).

A third cold spot is located in the southeast area of Hermosillo city (zone $12 \mathrm{~N}, 506,476.873 \mathrm{~m} \mathrm{E} / 3,209,328.331 \mathrm{~m} \mathrm{~N}$ ) and it is within a radial distance $<1.7 \mathrm{~km}$ from two L-H outliers (zone $12 \mathrm{~N}, 505,525.536 \mathrm{~m} \mathrm{E} / 3,211,442.412 \mathrm{~m} \mathrm{~N} ; 508,908.065 \mathrm{~m} \mathrm{E} /$ $3,211,548.116 \mathrm{~m} \mathrm{~N}$; and 508,094.383 $\mathrm{m} \mathrm{E} / 3,208,714.818 \mathrm{~m} \mathrm{~N}$ ). The remaining L-L cluster of the city locates in the northeast (zone $12 \mathrm{~N}, 504,805.865 \mathrm{~m} \mathrm{E} / 3,221,979.748 \mathrm{~m} \mathrm{~N}$ ) and is within a radial distance of $<2 \mathrm{~km}$ from three H-L outliers (zone $12 \mathrm{~N}, 504,714.700$ m E/ 3,223,193.458 m N; 504,179.552 m E/ 3,222,989.419 m N; and $504,781.238 \mathrm{~m} \mathrm{E} / 3,222,616.564 \mathrm{~m} \mathrm{~N}$ ).

This analysis identified fifty-eight spatial outliers (24 neighbourhoods with $\mathrm{H}-\mathrm{L}$ clusters, and $32 \mathrm{~L}-\mathrm{H}$ clusters) in Hermosillo city. Most of the low-high (L-H) outliers are close to the $\mathrm{H}-\mathrm{H}$ spatial clusters. With the exception of the previously mentioned three H-L outliers, the majority locates close to the high-high area and the L-H outliers.

Geographical patterns of breast cancer period prevalence (Years 2013 to 2019) at other communities of Hermosillo municipality: For the town Miguel Aleman, cluster analysis identified three cold spots and no hot spots (Figure 3). Those L-L clusters located in the west area of Miguel Aleman (zone $12 \mathrm{~N}, 450,619.036 \mathrm{~m} \mathrm{E} / 3,191,110.215 \mathrm{~m} \mathrm{~N} ; 450,416.466 \mathrm{~m} \mathrm{E} /$ 3,190,537.430 $\mathrm{m} \mathrm{N}$; and 451,394.391 m E/ 3,190,537.430 m N). Other rural communities (Bahia de Kino, El Choyudo, El Triunfo, La Yesca, Mesa del Seri, Real del Alamito, San Pedro El Saucito, Zamora) 
show no detectable patterns of breast cancer period prevalence. Due to the small sample size (Miguel Aleman, 22 cases, other rural communities, 14 cases) for locations other than Hermosillo city, those communities were not further analysed.

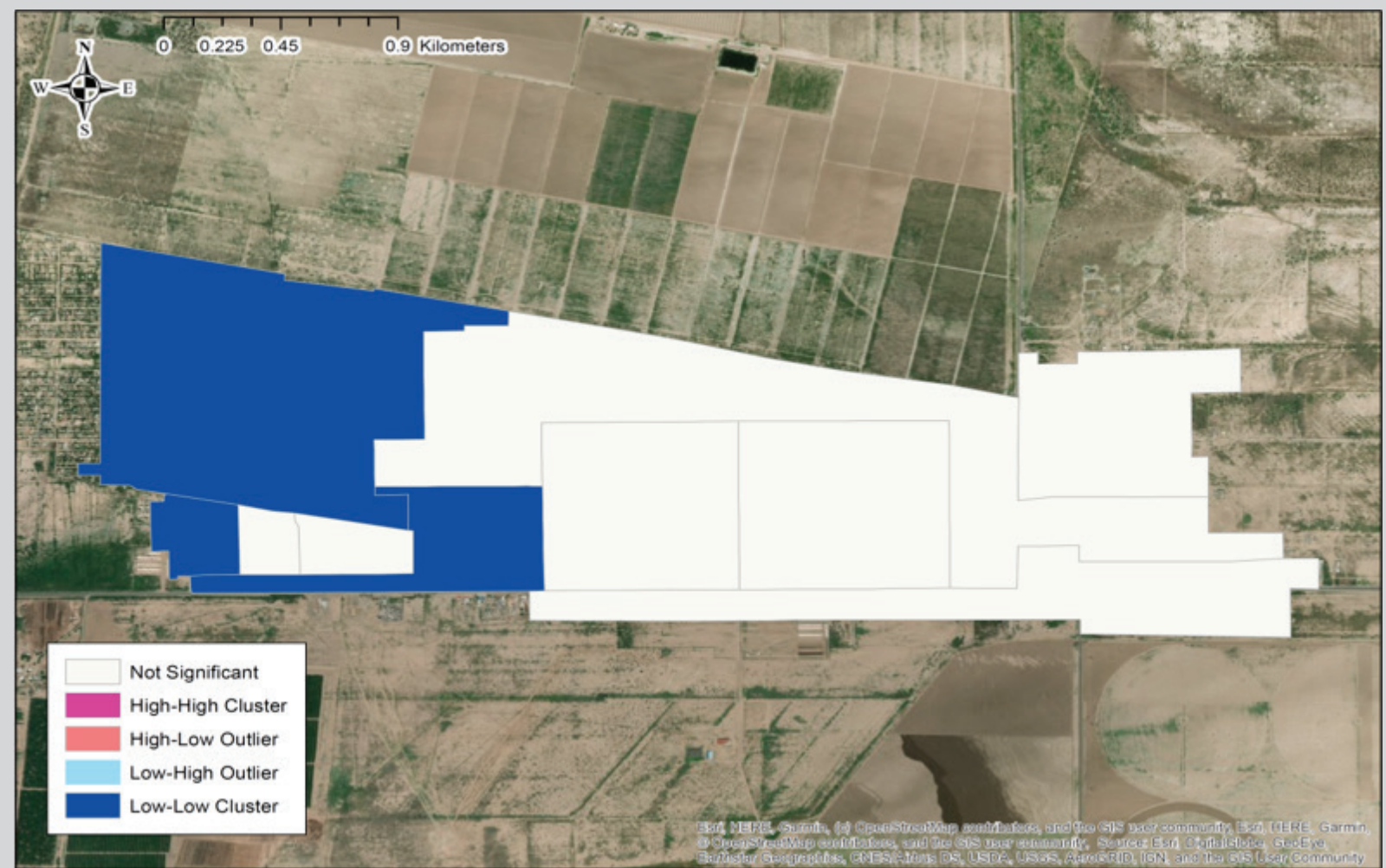

Figure 3: Spatial clusters (Local Anselin Moran's I) of breast cancer period prevalence (January 15t, 2013 to September $20^{\text {th }}, 2019$ ) at Miguel Aleman. source: INEGI Census 2010, clinical databases from hospitals HGE, CEO, Clínica del Noroeste, Hospital San José, and CIMA. projected coordinate system: WGS84 UTM 12 N. Geographic coordinate system: WGS84.

\section{Residential Exposure to PHS and Breast Cancer Risk in Hermosillo City}

Cutoffs for high- and low-industrialized neighbourhoods: First of all, it necessary to define what will be considered to be a highly industrialized neighbourhood. To find a cut-off for high and low industrialized neighbourhoods a regression analysis was performed where the neighbourhood density of cases is the response variable and number of industries of the neighbourhood is the explicative variable. The curve of the relationship shows small changes in the response variable, for the values from 1 to 6 industries and a big leap in the response for the value of 7 industries. The response variable keeps growing (for all cases except for 11 industries) when the number of industries was $\geq$ 8 , with at least one outlier for 21 industries. This implies that 7 industries could be a reasonable choice as a cut-off for high and low industrialized neighbourhoods. A neighbourhood is defined as a highly industrialized if its number is $\geq 7$.

Residential exposure according to the number of industries and breast cancer risk: The aim is to compare two subpopulations, high and low industrialized neighbourhoods for breast cancer risk assessment. The resulting odds ratio is $1.69(1.41,2.02)$ ( $p$-value $<$ 0.0001); (Figure 4).

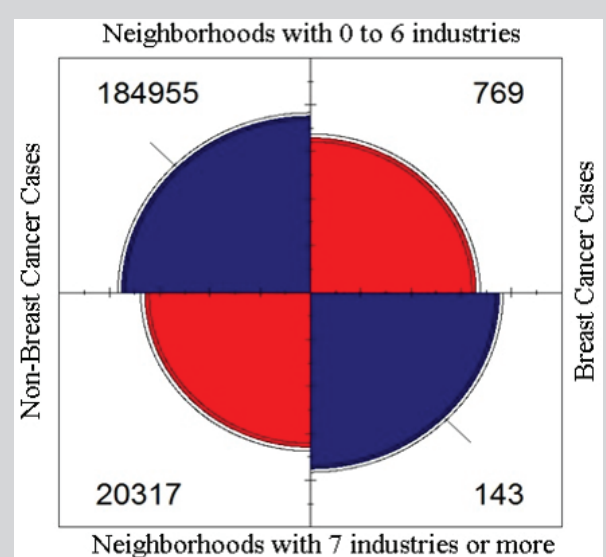

Figure 4: Comparison of the female population living in high and low industrialized neighbourhoods. OR $=1.69$ $(1.41,2.02)$ (p-value $<0.0001)$. 
Residential exposure by proximity to GPP and breast cancer risk: Two GPPs were reported by INEGI Census 2010, where the first (GPP1) located on the west side (zone $12 \mathrm{~N}, 493,612.626 \mathrm{~m}$ E/ 3,219,141.024 $\mathrm{m} \mathrm{N}$ ) of the city. The second one (GPP2) was located at the east side downtown (zone $12 \mathrm{~N}, 502,995.056 \mathrm{~m} \mathrm{E} /$ $3,217,038.065 \mathrm{~m} \mathrm{~N}$ ). First, GPP1 is analysed using a radial distance of $2 \mathrm{~km}$ and after the effect of GPP1 and GPP2 together (GGP) is calculated.

The odds ratio was calculated for breast cancer risk per neighbourhood exposed to GPP1 at distinct radial distances X. The cut-off values are defined for radial distance to GPP1: $0 \mathrm{~km} \leq \mathrm{X} \leq 2$ $\mathrm{km}$ (subpopulation 1), $2 \mathrm{~km}<\mathrm{X} \leq 4 \mathrm{~km}$ (subpopulation 2), $4 \mathrm{~km}<$ $\mathrm{X} \leq 6 \mathrm{~km}$ (subpopulation 3), and $6 \mathrm{~km}<\mathrm{X} \leq 8 \mathrm{~km}$ (subpopulation
4).The following comparisons were performed: Subpopulation 1 is compared with subpopulation 2 and the following $\mathrm{OR}=0.62(0.52$, 0.74 ) ( $p$-value $<0.00001$ ) was obtained; comparison between subpopulation 1 and subpopulation 3 produced an $\mathrm{OR}=0.39(0.32$, 0.47 ) ( $p$-value $<0.00001)$, and comparison between subpopulation 1 and 4 an OR $=0.41(0.33,0.51)(p$-value < 0.00001); (Table 1$)$.

Demographic data from INEGI Census 2010 served to estimate the number of breast cancer cases per 100,000 women for both GPP1-exposed and GPP1-nonexposed locations. The number of breast cancer cases per 100,000 women was the highest for subpopulation $1(n=606)$, followed by subpopulation $2(n=382)$, and for subpopulations 3 and $4(n=239)$ and $(n=254)$ which are very similar (Table 1 ).

Table 1: Comparison of the female population living in neighbourhoods at distinct radial distances (in km) to GPP1.

\begin{tabular}{|c|c|c|c|c|}
\hline $\begin{array}{c}\text { Radial Distance to } \\
\text { GPP1 (km) }\end{array}$ & $\begin{array}{c}\text { Number of Women } \\
\text { Without Breast Cancer } \\
\text { B }\end{array}$ & $\begin{array}{c}\text { Number of Women } \\
\text { with Breast Cancer C }\end{array}$ & Total & $\begin{array}{c}\text { Number of Breast } \\
\text { Cancer Cases per 100,000 } \\
\text { Women D }\end{array}$ \\
\hline $0 \mathrm{~km} \leq \mathrm{X} \leq 2 \mathrm{~km} \mathrm{~A}$ & 35,917 & 219 & 36,136 & 606 \\
\hline $2 \mathrm{~km}<\mathrm{X} \leq 4 \mathrm{~km} \mathrm{~A}$ & 75,639 & 290 & 75,929 & 382 \\
\hline $4 \mathrm{~km}<\mathrm{X} \leq 6 \mathrm{~km} \mathrm{~A}$ & 87,647 & 210 & 87,857 & 239 \\
\hline $6 \mathrm{~km}<\mathrm{X} \leq 8 \mathrm{~km} \mathrm{~A}$ & 56,118 & 143 & 56,261 & 254 \\
\hline
\end{tabular}

Table Abbreviations: (A) X represents radial distance; (B) Demographic data from INEGI Census 2010, women registered from ages $\geq 18$ years old; (C) Archive data from public hospitals (HGE, CEO) and private hospitals (CIMA, Clínica del Noroeste, Hospital San José) in Hermosillo; (D) The number of breast cancer cases per 100,000 persons was calculated as follows: 100,000x [x=number of women with breast cancer/total]; GPP1, Gas Power Plant 1.

The effect of the two GPPs is analysed in this section. The GPP2 has no population within a radial distance of $\mathrm{X} \leq 2 \mathrm{~km}$. However, the GPP2 reports inhabitants within a radial distance of $2 \mathrm{~km}$ $<\mathrm{X} \leq 4 \mathrm{~km}$. To evaluate population at-risk for both GPP, the total of inhabitants within $\mathrm{X} \leq 4 \mathrm{~km}$ for both GPP1 and GPP2 were considered as exposed. Therefore, two populations were considered for this second analysis. The subpopulation GPP-exposed were that of residents within a radial distance of $X \leq 4 \mathrm{~km}$. The GPP-nonexposed were those inhabitants within a radial distance of $X>4 \mathrm{~km}$. The analysis indicated an $\mathrm{OR}=1.55(1.36,1.77)(p$-value $<0.0001)$; (Figure 5).

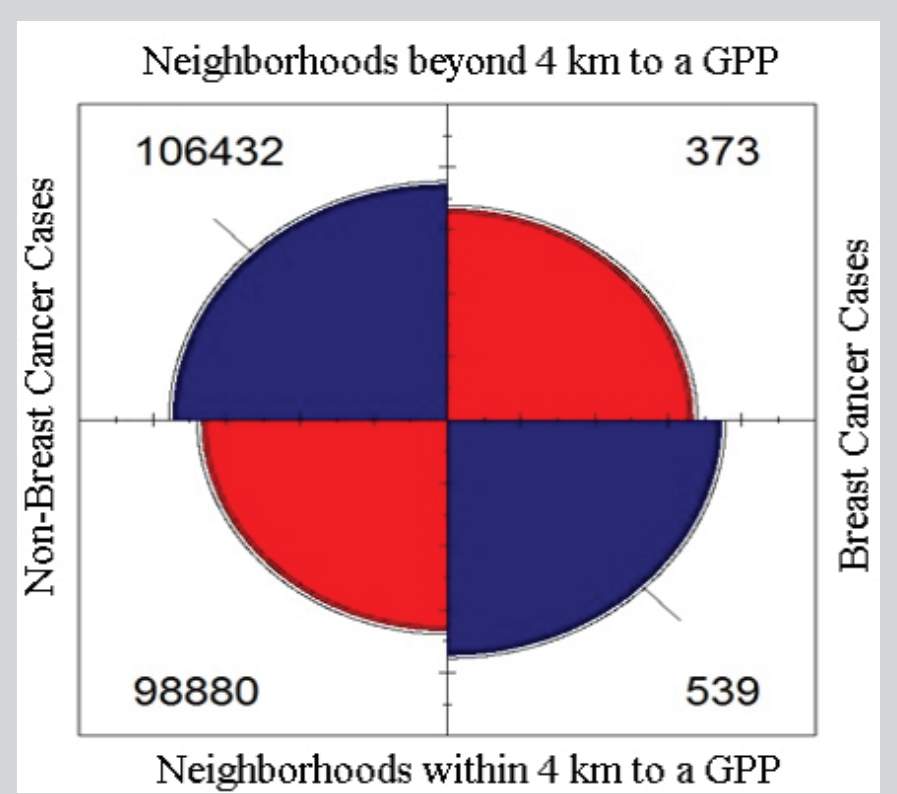

Figure 5: Comparison of the female population living in neighbourhoods within $\leq 4 \mathrm{~km}$ to a GPP to those living in neighbourhoods $>4 \mathrm{~km}$ to a GPP. OR $=1.55(1.36,1.77)(p$-value $<0.0001)$. 
Residential exposure to residual water sites (RWS) and breast cancer risk: The aim of this section is to assess the RWS as a possible risk factor by comparing the subpopulation residentially exposed to RWS with the RWS-nonexposed in Hermosillo city.

According to INEGI Census 2010, there are three RWS in Hermosillo. Two of them are located southwest (zone $12 \mathrm{~N}$, $497,593.732 \mathrm{~m} \mathrm{E} / 3,215,073.566 \mathrm{~m} \mathrm{~N}$; and 501,156.242 m E/ $3,215,639.044 \mathrm{~m} \mathrm{~N}$ ), while the third RWS at the west end of the city (zone 12 N, 492,334.789 m E/ 3,216,487.260 m N). Risk assessment to RWS exposure was evaluated by radial distance to an RWS (in km) of interest. Neighbourhoods within $3 \mathrm{~km}$ to an RWS were considered as RWS-exposed, while those locations beyond $3 \mathrm{~km}$ were classified as RWS-nonexposed. Women living in RWSexposed neighbourhoods had an OR $=1.45(1.26,1.66)(p$-value $<$ 0.0001 ) for breast cancer risk in comparison to those residing in RWS-nonexposed locations (Figure 6).

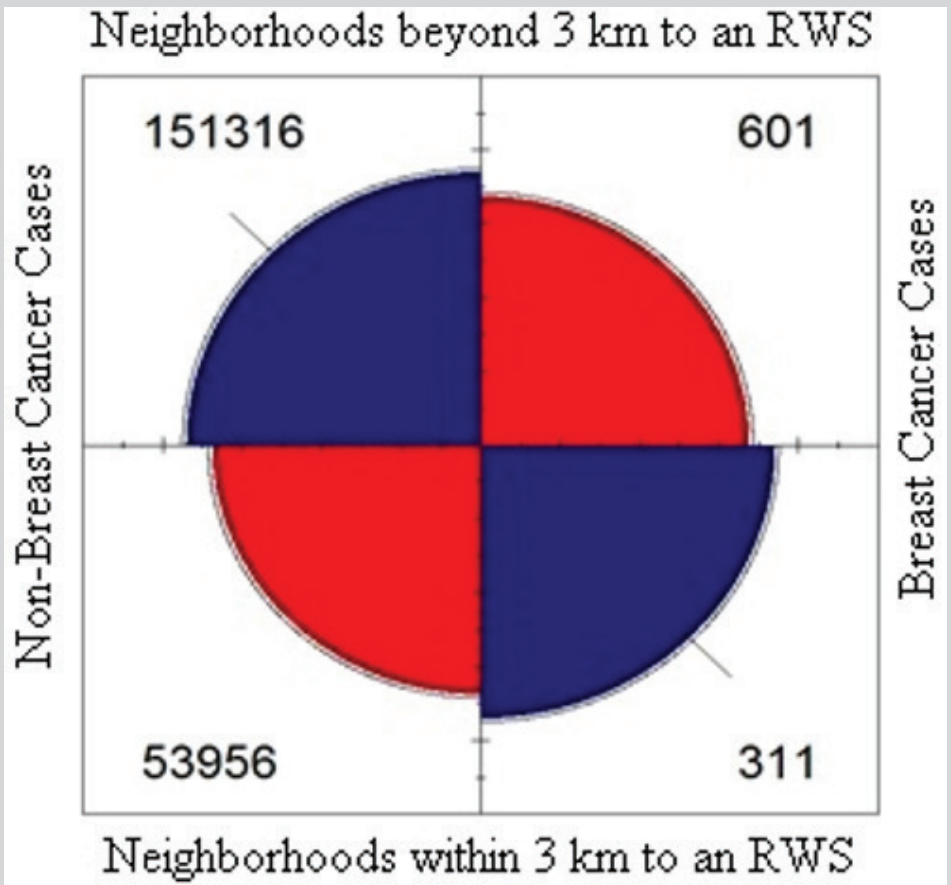

Figure 6: Comparison of the female population living in neighbourhoods within $3 \mathrm{~km}$ of an RWS to those residing in locations beyond $3 \mathrm{~km}$ from an RWS. OR $=1.45(1.26,1.66)$ ( $p$-value $<0.0001)$.

\section{Accumulative residential exposure to potentially hazardous} sites (PHS) and breast cancer risk in Hermosillo: It is expected that, if a population is exposed to more than one risk factor, then the number of cases, the ORs or the $\beta$ of the logistic regression model, increases. Those risk factors could be highly industrialized ( $\geq 7$ industries), GPP-exposed ( $\leq 4 \mathrm{~km})$, and RWS-exposed $(\leq 3 \mathrm{~km})$ neighbourhoods. There are eight possible combinations of risk factors. Those include the case where a risk factor is not present to the case where three risk factors are present. All possible comparisons, their $\mathrm{OR}$ and their logistic regression model are obtained and depicted in Table 2.

Females residentially exposed to one or more PHS had a higher risk than their non-exposed counterparts (all $p$-values $<0.0001$ ). There are two types of evidence: their ORs are increasing as the number of risk factor increases or the $\beta$ are increasing in the logistic regression model as the number of risk factor increases (monotonic property).

A mathematical model to predict the probability of PHSexposure by age is depicted as follows:

$$
\begin{aligned}
& \operatorname{logit}[\pi(x)]=\log \left(\frac{\pi(x)}{1-\pi(x)}\right)=\alpha+\beta x=-5.039+0.064 x \\
& \text { Where } \mathrm{x}=\text { Age }
\end{aligned}
$$

Where $\beta$ represents the change in the log odds associated with a unit of increase in $x$. The odds are multiplied by e $\beta$ for each unit of increase in $\mathrm{x}$. In this case, $\mathrm{e} 0.064=1.066$, which means an increase of $6.6 \%$ for the probability of living in a neighbourhood where the three risk factors are present.

The process to verify the monotonic property is the following: first, one of the factors must be chosen and the $\beta$ of the corresponding logistic regression model is registered; second, one factor is added to the model and the $\beta$ of the corresponding logistic regression model is registered. Note that this $\beta$ is greater than the previous one. Third, add the remaining factor to the model and the $\beta$ of the corresponding logistic regression model is registered. That process must be followed until all the variables are included in the model. If for a chosen factor, the $\beta$ is always greater than the $\beta$ of the previous model, the effect of the factor is monotone. If this property is satisfied for all the factors, it is said that the model is in monotone for all the factors. It is expected that, if a population is exposed to more than one risk factor, then the $\beta$ increases. Note that the monotonic property is satisfied for this breast cancer data set. Note that an increased behaviour is obtained also for the variable $\mathrm{OR}$, that behaviour is expected if the risk is increased.

\section{Age Distribution of Breast Cancer Population and PHS- Exposure}

Breast cancer development relates to an advanced age. For this reason, it expected to observe a different density of breast cancer cases in the older population ( $\geq 60$ years old). In order to establish a comparison of the PHS-exposed and non-exposed groups to three environmental risk factors (highly industrialized neighbourhoods, 
GPP, and RWS-exposed), two subpopulations were compared in terms of the age distribution. Subpopulation 1 depicted the age distribution of breast cancer cases residentially exposed to all three PHS, whereas subpopulation 2 represented that of breast cancer cases non-exposed to PHS (Figure 7).

Age distribution by PHS exposure (three risk factors) indicates an older population for PHS-exposed in comparison to that of
PHS-nonexposed (Figure 7). The median age for the distribution of the PHS non-exposed cases is lesser than the median age for the distribution of the PHS-exposed cases. Additionally, the 75 percentiles of the distribution of PHS non-exposed are lesser than the median of the distribution of PHS exposed. Previous statement means that if you are a case, you have a greater probability to live in a neighbourhood in which one or more risk factors are present.

Table 2: Comparison of the female population residing in neighbourhoods exposed to one, two, and three PHS with that of nonexposed-PHS locations.

\begin{tabular}{|c|c|c|c|}
\hline $\begin{array}{l}\text { Comparison of Female Population Living in } \\
\text { PHS-Exposed } \\
\begin{array}{l}\text { Locations vs Nonexposed-PHS } \\
\text { Neighbourhoods A }\end{array}\end{array}$ & Odds & $\begin{array}{l}\text { Ratio for Breast } \\
\text { Cancer Risk }\end{array}$ & Logistic Regression Model \\
\hline $\begin{array}{cc}\text { High-industrialized neighbourhoods vs nonexposed-PHS } \\
\text { locations }\end{array}$ & & $1.69(1.41,2.02)$ & $\operatorname{logit}[\pi(x)]=\log \left(\frac{\pi(x)}{1-\pi(x)}=\alpha+\beta x=-3.85+0.038 x\right.$ \\
\hline GPP-exposed neighbourhoods vs nonexposed-PHS locations & & $1.55(1.36,1.77)$ & $\operatorname{logit}[\pi(x)]=-1.26+0.0302 x$ \\
\hline RWS-exposed neighbourhoods vs nonexposed-PHS locations & & $1.45(1.26,1.66)$ & $\operatorname{logit}[\pi(x)]=-1.94+0.023 x$ \\
\hline $\begin{array}{c}\text { GPP and RWS-exposed neighbourhoods vs nonexposed-PHS } \\
\text { locations }\end{array}$ & & $1.68(1.44,1.96)$ & $\operatorname{logit}[\pi(x)]=-4.28+0.059 x$ \\
\hline $\begin{array}{c}\text { High-industrialized, RWS-exposed neighbourhoods vs } \\
\text { nonexposed-PHS locations }\end{array}$ & & $2.03(1.61,2.55)$ & $\operatorname{logit}[\pi(x)]=-5.14+0.057 x$ \\
\hline $\begin{array}{c}\text { High-industrialized, GPP-exposed neighbourhoods } v s \\
\text { nonexposed-PHS locations }\end{array}$ & & $2.10(1.71,2.58)$ & $\operatorname{logit}[\pi(x)]=-2.12+0.035 x$ \\
\hline $\begin{array}{c}\text { High-industrialized, RWS-exposed \& GPP-exposed } \\
\text { neighbourhoods vs nonexposed-PHS locations }\end{array}$ & & $2.29(1.80,2.91)$ & $\operatorname{logit}[\pi(x)]=-5.03+0.0642 x$ \\
\hline
\end{tabular}

Table Abbreviations: (A) Female population by neighbourhood was $\geq 18$ years old. Those included non-breast cancer cases as reported by INEGI Census 2010, and breast cancer cases as reported by local hospitals (HGE, CEO, CIMA, Hospital San José, Clínica del Noroeste) at Hermosillo city from the period January $1^{\text {st }}, 2013$ to September $20^{\text {th }}, 2019$. PHS, Potential Hazardous Sites. GPP, Gas Power Plant. RWS, residual water site.

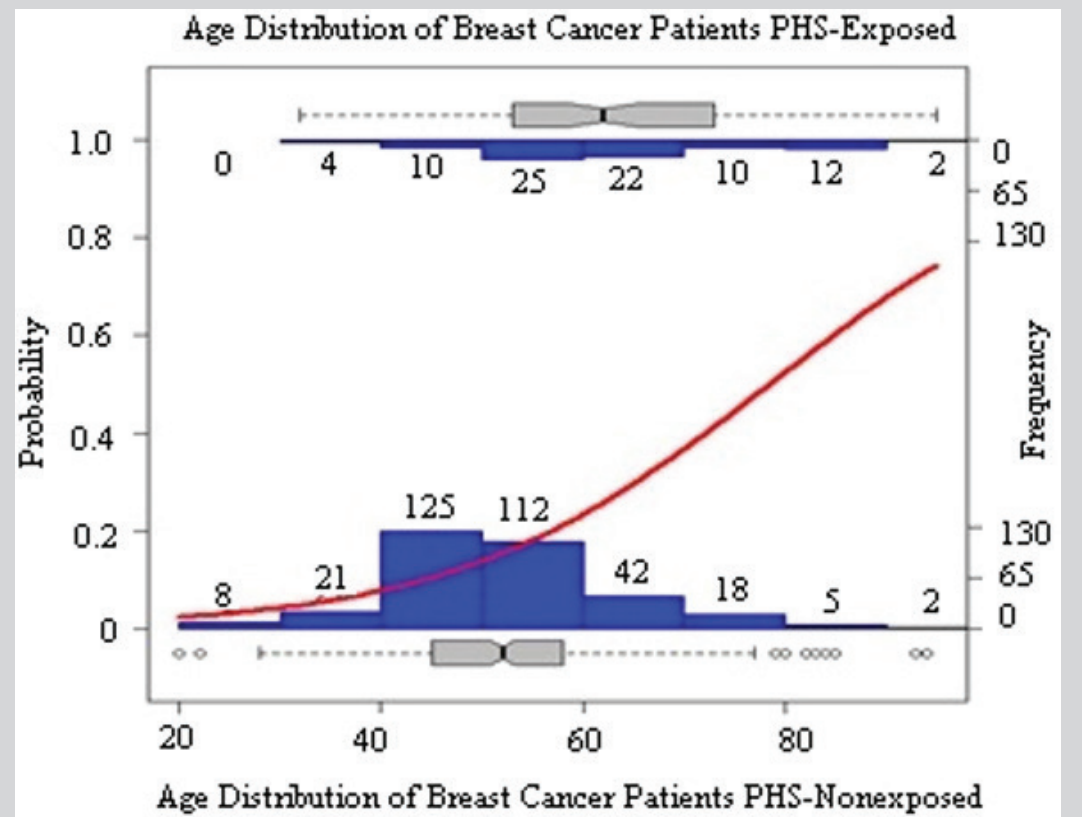

Figure 7: Comparison of the age distribution of breast cancer patients residentially exposed to three PHS (highly industrialized neighbourhoods, GPP, and RWS-exposed) versus their non-exposed counterparts.

\section{DISCUSSION}

This observational retrospective study evaluated the associations between environmental risk factors and breast cancer risk. Main findings show monotony between the number of risk factors (highly industrialized neighbourhoods, GPP-exposed, and RWS-exposed) and the number of breast cancer cases (OR, b) in
Hermosillo city. The results indicate breast cancer risk is higher for females living in neighbourhoods with HAPs' sources.

\section{Spatial Heterogeneity of Breast Cancer Period Prevalence in Hermosillo Municipality}

Hermosillo municipality presents statistically significant 
spatial heterogeneity for breast cancer prevalence during the period 2013 to 2019: Spatial cluster analysis indicated six hot spots in Hermosillo city, the capital of Sonora state. All the highhigh clusters identified at the capital are in proximity to potentially hazardous sites (PHS). Other rural communities in Hermosillo municipality showed no evidence of hot spots.

Other environmental studies provided evidence of geographic heterogeneity, in the present case, about breast cancer heterogeneity. Soto-Perez-de-Celis indicated higher mortality rates in the Southwest (APC 2.7\%, $p<0.05$ ) and Center-North regions (APC $1.7 \%, p<0.05$ ) of Mexico in the period 2001 to 2011 SotoPerez-de-Celis et al. [5].

Likewise, Castrezana-Campos reported 120 municipalities with the highest morbidity and mortality rates for breast cancer, where environmental pollutants Castrezana-Campos [6] are studied as non-genetic factors for this disease. Hermosillo was one of the 120 municipalities reported by Castrezana-Campos [6].

The present research provides evidence of regional variations of breast cancer prevalence in Hermosillo municipality during a specific period of time (January $1^{\text {st }}, 2013$ to September $20^{\text {th }}$, 2019) therefore contributing to a better understanding of the possible associations between breast cancer and HAPs. To the best of our knowledge, there are no prior reports on the geographical distribution of breast cancer prevalence by neighbourhood in Hermosillo municipality.

Higher breast cancer risk is present in PHS-exposed neighbourhoods: In order to explore potential associations, the OR was calculated between residential exposure to PHS and non-breast cancer residents per unit (neighbourhood). Only women equal or older than 18, as registered by INEGI Census 2010, were considered in this study. This approach included all the neighbourhoods across Hermosillo and was not restricted to those locations previously identified as $\mathrm{H}-\mathrm{H}$ spatial clusters.

Results for this study give evidence that breast cancer risk is higher for women residing in neighbourhoods where sources of hazardous air pollutants (HAPs) are present. The evidence is exhibited in terms of $\mathrm{OR}$, in the number of cases, and different subpopulation distributions. The OR for women residing in highly industrialized ( $\geq 7$ industries) neighbourhoods and lowindustrialized ( $\leq 6$ industries) neighbourhoods is 1.69 ( $p$-value < 0.0001). For GPP-exposed, the number of breast cancer cases per 100,000 persons increased by residential proximity to a GPP1 ( $n=606$ for $\mathrm{X} \leq 2 \mathrm{~km}, n=382$ for $2 \mathrm{~km}<\mathrm{X} \leq 4 \mathrm{~km}, n=239$ for 4 $\mathrm{km}<\mathrm{X} \leq 6 \mathrm{~km}$, and $n=254$ for $6 \mathrm{~km}<\mathrm{X} \leq 8 \mathrm{~km}$, where $\mathrm{X}$ is the radial distance, all $p$-values $<0.0001$ ), and may indicate a higher prevalence of this disease with a closer exposure to HAPs' produced by GPP1. For GPP = (set of women possibly affected by GGP1 and GPP2) where women residing in GPP-exposed locations $(\leq 4 \mathrm{~km})$ were at higher risk $(\mathrm{OR}=1.55, p$-value $<0.0001)$ than those living in GPP-nonexposed neighbourhoods ( $>4 \mathrm{~km})$.

Other studies evaluated the exposure to HAPs and breast cancer risk, where women residing in urban areas presented a higher risk for breast malignancies Garcia et al. [8]; Liu et al. [9]. Hormonepositive breast cancers were related to long-term exposure to air pollutants such as acrylamide, benzidine, carbon tetrachloride, ethylidene dichloride, and vinyl chloride Garcia et al. [8], while hormone-negative breast cancers were related to cadmium exposure Liu et al. [9]. However, the link between HAPs and breast cancer burden is not consistent through the literature. Hart et al.
[12] reported no evidence of an increased risk for exposure to HAPs.

In Mexico, only one study aimed for HAPs and breast cancer risk assessment Castrezana-Campos [6], where 120 municipalities were correlated with high $\mathrm{NOx}$ and $\mathrm{SO}_{2}$ emissions as reported by the Commission for Environmental Cooperation (CCA) in 2010. Our work contributes to the unmet need for breast cancer risk assessment to HAPs' exposure in a community considered at-risk, given its high-industrialized activities.

The link between exposure to contaminated water sources (CWS) and breast cancer risk is also a matter of debate. Investigations suggest chemicals ingested in water, like tetrachloroethylene (PCE) and organic solvents, accumulate in the breast and increase the risk for cancer development Labreche et al. [17]. Few studies reported a moderate increase in cancer burden given PCE-exposure Aschengrau et al. [18]; Gallagher et al. [19]. Others report no associations between CWS-exposure and breast cancer risk Brody et al. [20].

In Mexico, only one study aimed at evaluating chemical exposure in water sources with breast cancer risk. Where the high incidences of mortality and morbidity in 120 municipalities were associated with chemicals in water sources. In the present work, women were at higher risk for breast cancer when living in RWS-exposed $(\leq 3$ $\mathrm{km})$ neighbourhood in comparison to those residing in an RWSnonexposed location, with an OR $=1.45$ ( $p$-value $<0.0001$ ).

It is expected that if a population is exposed to more than one risk factor, then the number of cases, or the ORs, or the $\beta$ of the logistic regression model, increase. Those risk factors could be highly industrialized neighbourhoods ( $\geq 7$ industries), GPP-exposed $(\leq 4 \mathrm{~km})$, and RWS-exposed $(\leq 3 \mathrm{~km})$ neighbourhoods. Women residentially exposed to one or more PHS had a higher risk than their non-exposed counterparts (all $p$-values $<0.0001$ ). There are three types of evidence: their ORs, the $\beta$ of the logistic regression model and the number of cases, which increase as the number of risk factor increases. That monotonic property is evidence of increasing risk as the number of risk factors present increases. To the best of our knowledge, this work is the first in Hermosillo, Sonora to propose a model of cumulative residential exposure to hazards in a community considered at-risk for breast cancer. Larger samples are required to confirm our findings.

\section{Strengths and Limitations}

The most important strength of this research is that results provided evidence that breast cancer risk is higher for women residing in neighbourhoods where sources of hazardous air pollutants (HAPs) are present. A confirmation of this fact is the monotonic relation between the number of risk factors present and the increase of the $\beta$ coefficient in the logistic regression model. An additional strength is that the sample includes only cases with a verifiable ID address with at least 10 years of same residence. This was an advantage in assessing residential expose to PHS.

This study has several limitations related to the lack of information available on water supply, indoor air quality, and air pollutants other than those produced by anthropogenic sources across Hermosillo municipality. Future work may include this information.

\section{CONCLUSION}

Our hypothesis is that there are possible associations between breast cancer and risk factors such as highly industrialized 
neighbourhoods, GPP and RWS in Hermosillo Sonora, Mexico. Evidence of those possible associations are expressed in terms of $\mathrm{OR}$, a number of cancer cases and the coefficient $\beta$ from the logistic regression model. This finding is meaningful because it could be useful for developing current environmental and public health policies. Additionally, hospital administrations could allocate resources in order to satisfy the possible demands of health services implicated in breast cancer treatments. More studies may focus on breast cancer prevention policies by reducing exposure to environmental hazards in high-risk populations.

\section{ACKNOWLEDGMENT}

The first author of this work was the recipient of the Consortium for Arizona - Mexico Arid Environments (CAZMEX) Award 2018 for Postdoctoral Stays University of Arizona - CONACyT. Special thanks to CAZMEX funding and their heads, Dr. Christopher Scott and Dr. Benjamin T. Wilder, from the University of Arizona, Tucson, AZ, USA

This study was reviewed and approved by the Institutional Review Board (IRB) of the University of Sonora (file CEI-UNISON $12 / 2019$, IRB approval on May $\left.7^{\text {th }}, 2019\right)$, the Health Secretary of Sonora (file SSS-DGEC-0493/2019, IRB approval on April 23 ${ }^{\text {rd }}$, 2019), HGE (file SSS-HGE-CI-2019-005, IRB approval on May $3^{\text {rd, }}$ 2019), CEO (IRB approval on June $28^{\text {th }}, 2019$ ), CIMA (IRB approval on April 26 ${ }^{\text {th }}, 2019$ ), Hospital San José (IRB approval on April 2 ${ }^{\text {nd }}, 2019$ ), and Clínica del Noroeste (CONBIOETICA26CHB02720170410, IRB approval on April 5 $\left.5^{\text {th }}, 2019\right)$.

The authors of this work want to thank the hospital facilities HGE, CEO, CIMA, Clínica del Noroeste, and Hospital San José and their staff for granting access to the clinical files. Special thanks to all the physicians collaborating in this work: Dr. Enrique AvilaMonteverde of the Clinica del Noroeste; Dr. Jose Heliodoro GonzalezZepeda of the Hospital San Jose; Dr. Luis Felipe Munguia-Ibarra of the Hospital General del Estado de Sonora Dr. Ernesto Ramos Bours (HGE); Dr. Karla G. Aguilar-Gutierrez, Dr. Cynthia Roja-Camarena, Dr. Luis C. Durazo-Cons, Dr. Carlos D. Luque-Morales, Dr. Wendy B. Aguilar-Peraza, and Dr. Jorge A. Cordon-Guillen of the Centro Estatal de Oncología Dr. Ernesto Rivera Claisse (CEO); and Dr. Baldemar Corral-Villegas of CIMA. We are very thankful to the teaching heads M.S. Maru Eugenia from Clinica del Noroeste, Dr. Carlos GonzalezBecuar from HGE, Shelene Tarazon from HGE, and Dr. Frankfer Urias from CEO, for their support in clinical data acquisition.

Special thanks to Armando Yanez from INEGI, for his help in providing an important quantity of the geospatial data. Special thanks to Tanyha Zepeda from the University of Arizona, for her assistance with REDCap platform.

\section{AVAILABILITY OF DATA}

The data that support the findings of this study are available on request from the corresponding author, [DVG]. The data are not publicly available due to relevant data protection laws in Mexico for the protection and privacy of human subjects participating in this research.

\section{REFERENCES}

1. Ferlay J, Soerjomataram I, Dikshit R, Eser S, Mathers C, et al. (2015) Cancer incidence and mortality worldwide: sources, methods and major patterns in GLOBOCAN 2012. Int J Cancer 136(5): E359-386.

2. Instituto Nacional de Estadística y Geografía (2014) Estadísticas a propósito del Día mundial de la lucha contra el cáncer de mama 19 de octubre. INEGI, México.
3. Mohar-Betancourt A, Reynoso-Noverón N, Armas-Texta D, GutiérrezDelgado C, Torres-Domínguez JA (2017) Cancer trends in Mexico: Essential data for the creation and follow-up of public policies. J Glob Oncol 3(6): 740-748.

4. Health secretary of Mexico (2002) Programa de Acción: Cáncer de mama. SS, México.

5. Soto-Perez-de-Celis E, Chavarri-Guerra Y (2016) National and regional breast cancer incidence and mortality trends in Mexico 2001-2011: Analysis of a population-based database. Cancer Epidemiol 41: 24-33.

6. Castrezana-Campos M (2017) The geography of Mexico breast cancer. Investigaciones Geográficas UNAM.

7. Instituto Nacional de Estadística y Geografía (2015) Defunciones de mujeres por tumor maligno de la mama por entidad federativa y grupo quinquenal de edad, 2010 a 2015. INEGI, Mexico.

8. Garcia E, Hurley S, Nelson DO, Hertz A, Reynolds P (2015) Hazardous air pollutants and breast cancer risk in California teachers: a cohort study. Environ Health 14: 14.

9. Liu R, Nelson D0, Hurley S, Hertz A, Reynolds P (2015) Residential exposure to estrogen disrupting hazardous air pollutants and breast cancer risk: the California teachers' study. Epidemiology 26(3): 365-373.

10. (2011) Hoja informativa sobre sustancias peligrosas. New Jersey, USA.

11. World Health Organization. (2007) Population health and waste management: scientific data and policy options. Report of a WHO workshop. Rome, Italy.

12. Hart JE, Bertrand KA, DuPreN, James P, Vieira VM, et al. (2018) Exposure to hazardous air pollutants and risk of incident breast cancer in the nurses' health study II. Environ Health 17(1): 28.

13. Comisión de Cooperación Ambiental de América del Norte (2010) México Quinta Comunicación Nacional ante la Convención Marco de las Naciones Unidas sobre el Cambio Climático. Portal de América del Norte sobre contaminantes precursores del cambio climático.

14. Kuch HM, Ballschmiter K (2001) Determination of endocrine-disrupting phenolic compounds and estrogens in surface and drinking water by HRGC-(NCI)-MS in the picogram per liter range. Environ Sci Technol 35(15): 3201-3206.

15. Rudel RA, Melly SJ, Geno PW, Sun G, Brody JG (1998) Identification of alkylphenols and other estrogenic phenolic compounds in wastewater, septage and groundwater on cape cod, Massachusetts. Environ Sci Technol 32(7): 861-869.

16. Moran MJ, Zogorski JS, Squillace PJ (2007) Chlorinated solvents in groundwater of the United States. Environ Sci Technol 41(1): 74-81.

17. Labreche FP, Goldberg MS (1997) Exposure to organic solvents and breast cancer in women: a hypothesis. Am J Ind Med 32: 1-14.

18. Aschengrau A, Rogers S, Ozonoff D (2003) Perchloroethylenecontaminated drinking water and the risk of breast cancer: additional results from cape cod, Massachusetts, USA. Environ Health Perspect 111(2): 167-173.

19. Gallagher LG, Vieira VM, Ozonoff D, Webster TF, Aschengrau A (2011) Risk of breast cancer following exposure to tetrachloroethylenecontaminated drinking water in Cape Cod, Massachusetts: reanalysis of a case-control study using a modified exposure assessment. Environ Health 10: 47

20. Brody JG, Aschengrau A, McKelvey W, Swartz CH, Kennedy T, et al. (2006) Breast cancer risk and drinking water contaminated by wastewater: a case control study. Environ Health 5: 28.

21. Comisión Nacional del Agua (2012) Estadísticas del Agua en México edición 2012. Comisión Nacional del Agua, SEMARNAT, México.

22. Sistema Nacional de Información de Salud (2011) Estadísticas del cáncer de mama. SINAIS, México.

23. Hiatt RA, Brody JG (2018) Environmental determinants of breast cancer. Annu Rev Public Health 39: 113-133.

24. INEGI (2010) INEGI Censo de Población y Vivienda 2010, México. 
25. Harris PA, Taylor R, Thielke R, Payne J, Gonzalez N, et al. (2009) Research electronic data capture (REDCap): A metadata-driven methodology and workflow process for providing translational research informatics support. J Biomed Inform 42(2): 377-381.

26. US Department of Health and Human Services, Office of the Secretary, Office for Civil Rights \& Ocr. (2015) Methods for De-identification of PHI.

27. Leyes Federales de México (2010) Ley Federal de Protección de Datos Personales en Posesión de los Particulares.

28. Diario Oficial de la Federación (2012) NORMA Oficial Mexicana NOM024-SSA3-2012, Sistemas de información de registro electrónico para la salud.

29. Brender JD, Maantay JA, Chakraborty J (2011) Residential proximity to environmental hazards and adverse health outcomes. AJPH 101 : S37-S52.

30. Huang PL (2009) A comprehensive definition for metabolic syndrome. Dis Model Mech 2(5-6): 231-237.

31. Secretaría de Salud (2003) Reglamento de la Ley General de Salud en Materia de Prestación de Servicios de Atención Médica.

32. Leal-Soto SD, Valenzuela-Quintanar AI, Gutiérrez-Coronado ML Bermúdez-Almada MC, García-Hernández J, et al. (2014) Residuos de plaguicidas organoclorados en suelos agrícolas (norte y centro) del estado de Sonora. Terra Latinoamericana 32(1): 2014

33. Campaña Contra el Gusano Rosado en Sonora. (1975) Boletín no: 34 marzo-abril. Hermosillo, Sonora.
34. Secretaría de Agricultura y Recursos Hidráulicos (1979) Anuario estadístico: Año agrícola 1977-1978. México: SARH, 1979.

35. Instituto Nacional de Ecología y Cambio Climático-Comisión para la Cooperación Ambiental. (2010). Guía para la validación de métodos alternos de análisis. INECC-CCA. DF, Mexico.

36. Environmental Protection Agency (2011) The US Environmental Protection Agency (USEPA). List of minimum limits of risk (MRL) for pesticides in soil.

37. Garcia-Rico L, Meza-Figueroa D, Gandolfi AJ, Del Rio-Salas R, Romero FM, et al. (2016) Dust metal sources in an urbanized arid zone: Implications for health-risk assessments. Arch Environ Contam Toxicol 70(3): 522533.

38. Gomez-Alvarez A, Ortega-Romero P, Yocupicio-Anaya MTJ (1989) Niveles de metales pesados en el Río Sonora y su afluente el Río Bacanuchi, Sonora, Mexico. Ecologica. 1(2)10-20.

39. Gomez-Alvarez A, Grijalva Chon JM (1997) Estudio de la calidad físicoquímica del agua de la presa Abelardo L Rodríguez, Sonora. Boletín del Departamento de Geología de la Universidad de Sonora 14(1): 47-62.

40. Garcia-Rico L, Tejeda-Valenzuela L, Jara-Marini ME, Gomez-Alvarez A (2011) Dissolved and particulate metals in water from Sonora Coast: a pristine zone of Gulf of California. Environ Monit Assess. 176(1-4): 109123.

41. Calderon V (2010) Analysis of environmental samples with the agilent 730-ES Following US EPA Guidelines. Application Note. Inductively Coupled Plasma-Optical Emission Spectrometers. Agilent Technologies, Inc., USA. 